\title{
DETERMINANT MODEL OF DISTRICT/CITY GOVERNMENT FINANCIAL PERFORMANCE IN SUMATERA UTARA PROVINCE
}

\author{
M. Firza Alpi ${ }^{1}$, Baihaqi Ammy ${ }^{2}$ \\ ${ }^{1,2}$ Faculty of Economics and Business, Universitas Muhammadiyah Sumatera Utara \\ E-mail: ${ }^{1)}$ m.firzaalpi@umsu.ac.id $*{ }^{*}$ baihaqiammy@umsu.ac.id
}

\begin{abstract}
The results showed that Capital Expenditure had no partial effect on Financial Performance, Size of Local Government partially affected Financial Performance, and the Remaining Budget Financing partially affected Financial Performance. Partially, Capital Expenditure, Size of Local Government, and Remaining Budget Financing together have an effect on the Financial Performance of district/city governments in North Sumatra Province. The R-Square value is 0.815 or $81.5 \%$. This shows that the variables of Capital Expenditure, Size of Local Government, and Remaining Budget Financing are able to explain the Financial Performance variable of $81.5 \%$. While the remaining $18.5 \%$ is explained by other variables outside the study.
\end{abstract}

\section{Keywords: Capital Expenditure, Size of Local Government, Silpa.}

\section{INTRODUCTION}

Capital expenditure is also used as an independent variable in this study because capital expenditure activities also affect regional revenue growth which is a projection of local government financial performance. The results of the study (Yulia, Astiti DN, 2016) show that the allocation of funds for more capital expenditures can later help the regions to obtain financial sources so as to generate regional income, so this has implications for improving the financial performance of local governments. One of the capital expenditure activities is infrastructure development. High infrastructure development can be said to be able to increase the growth of local government financial performance (Puspitasari, NLP Lindri., M. Pradana Adiputra., 2015). According to (Andirfa, Mulia., Hasan Basri., 2016), It is hoped that the infrastructure contained in an area will be able to create efficiency in various sectors, increase community productivity so that this will have implications for better local government financial performance. (Mulyani, 2017) also found that capital expenditure had a significant positive effect on local government financial performance. In this study, total revenue was chosen as a benchmark in determining the size of a local government. Total income was chosen because its value is more stable than the number of employees or the total production of an area. Local governments with large sizes are required to carry out transparency in financial management as a form of public accountability through the disclosure of more information in financial reports. community productivity increases so that this will have implications for better local government financial performance. (Mulyani, 2017) also found that capital expenditure had a significant positive effect on local government financial performance. In this study, total revenue was chosen as a benchmark in determining the size of a local government. Total income was chosen because its value is more stable than the number of employees or the total production of an area. Local governments with large sizes are required to carry out transparency in financial management as a form of public accountability through the disclosure of more information in financial reports. community productivity increases so that this will have implications for better local government financial performance. (Mulyani, 2017) also found that capital expenditure had a significant positive effect on local government financial performance. In this study, total revenue was chosen as a benchmark in determining the size of a local government. Total income was chosen because its value is more stable than the number of employees or the total production of an area. Local governments with large sizes are required to carry out transparency in financial management as a form of public accountability through the disclosure of more information in financial reports. 2017) also found that 
Determinant Model Of District/City Government Financial Performance In Sumatera Utara Province DOI: $10.54443 /$ ijerlas.v1i2.73

capital expenditure had a significant positive effect on local government financial performance. In this study, total revenue was chosen as a benchmark in determining the size of a local government. Total income was chosen because its value is more stable than the number of employees or the total production of an area. Local governments with large sizes are required to carry out transparency in financial management as a form of public accountability through the disclosure of more information in financial reports. 2017) also found that capital expenditure had a significant positive effect on local government financial performance. In this study, total revenue was chosen as a benchmark in determining the size of a local government. Total income was chosen because its value is more stable than the number of employees or the total production of an area. Local governments with large sizes are required to carry out transparency in financial management as a form of public accountability through the disclosure of more information in financial reports. Total income was chosen because its value is more stable than the number of employees or the total production of an area. Local governments with large sizes are required to carry out transparency in financial management as a form of public accountability through the disclosure of more information in financial reports. Total income was chosen because its value is more stable than the number of employees or the total production of an area. Local governments with large sizes are required to carry out transparency in financial management as a form of public accountability through the disclosure of more information in financial reports.

The size of the local government is a large or small variable of a particular local government which is generally measured by total revenue. Size Local governments with large assets are considered to have the potential to serve the community better. Automatically local government performance will increase according to the size of its assets (Alvini, 2018). The size of the regional government is indicated by the size of the assets owned by a region. Assets can represent how big the government is, the bigger the assets, the more capital invested (Nosihana, A \& Yaya, 2016). Another source of funding for the allocation of capital expenditures for the provision of various public facilities is regional revenues sourced from the Excess Budget Financing (SiLPA) of the previous fiscal year. According to the Regulation of the Minister of Home Affairs (Permendagri) No. 13 of 2006, SiLPA is the remaining funds obtained from the actualization of regional budget revenues and expenditures for one period. (Liliana, Bunescu, 2011) stated that the relationship between government revenues and government expenditures is important, given its relevance for policy, especially with regard to the budget deficit.

Table I Data on Capital Expenditures, Size of Local Governments, Excess Budget Financing and Financial Performance of Local Governments

\begin{tabular}{|l|c|c|c|c|c|}
\hline \multicolumn{1}{|c|}{ County/City } & Year & $\begin{array}{c}\text { Capital } \\
\text { Expenditure }\end{array}$ & $\begin{array}{c}\text { Local } \\
\text { Government Size }\end{array}$ & $\begin{array}{c}\text { Remaining More } \\
\text { Budget Financing }\end{array}$ & $\begin{array}{c}\text { Financial } \\
\text { performance }\end{array}$ \\
\hline $\begin{array}{l}\text { Regency. South } \\
\text { Tapanuli }\end{array}$ & 2015 & $277,972,000,000$ & $\begin{array}{c}1,0222,992,164,00 \\
0\end{array}$ & $513,235,000,000$ & $98,438,745,861$ \\
\hline & 2016 & $317,665,584,012$ & $1,228,589,046,294$ & 521.022 .085 .585 & $90,666,249,315$ \\
\hline & 2017 & 251.102 .481 .128 & $1,191,626,643,686$ & $502,785,089,674$ & $81,435.846,816$ \\
\hline & 2018 & $288,503,471,683$ & $1,243,242,590,237$ & 484.939 .012 .817 & $110,678,075,237$ \\
\hline $\begin{array}{l}\text { Regency. } \\
\text { Middle Tapanuli }\end{array}$ & 2019 & $347,972,064,954$ & $1,470,808,838,761$ & $526,800,806.019$ & $138,751,607,368$ \\
\hline & 2015 & $169,627,000,000$ & $860,362,124,000$ & $502,078,000,000$ & $47,720,444,960$ \\
\hline & 2017 & $248,422,863,200$ & $1,168,384,127,000$ & $544,891,590,000$ & $64,005,291,000$ \\
\hline & 2018 & 293.563 .418 .000 & $1,068,524,630,924$ & $499,089,733,464$ & $72,369,935,497$ \\
\hline $\begin{array}{l}\text { Regency. North } \\
\text { Tapanuli }\end{array}$ & 2019 & $186,108,916,165$ & $1,212,955,189,000$ & $495,825,877,300$ & $100,000,000,000$ \\
\hline
\end{tabular}




\begin{tabular}{|l|c|c|c|c|c|}
\hline & 2016 & $256,894,018,413$ & $1,239,318,179,053$ & $614,667,423,737$ & $67,183,704,000$ \\
\hline & 2017 & $153,059,693,043$ & $1,160,979,706.672$ & $507,242,104,662$ & $94,623,508,995$ \\
\hline & 2018 & $175,999,699,890$ & $1,282,961,917,096$ & $512,096,184,012$ & $110,0008,590,000$ \\
\hline & 2019 & $199,595,162,428$ & 1.334 .096 .896 .133 & $548,212,671,547$ & $123,600,0006.032$ \\
\hline $\begin{array}{l}\text { Regency. Toba } \\
\text { Samosir }\end{array}$ & 2015 & 132.858 million & $788,673,453,446$ & $458,631,000,000$ & $34,197,975,019$ \\
\hline & 2016 & $142,747,216,618$ & $971,943,461.117$ & $476,484,578,060$ & $37,451,580,462$ \\
\hline & 2017 & $183,534,119,069$ & $1,100,676,088,660$ & $420,982,595,251$ & $44,367,570,060$ \\
\hline & 2018 & $133,444,911,040$ & $985,869,387,152$ & 423.380 .139 .162 & $50,147,346,275$ \\
\hline & 2019 & $135,812,733,116$ & $1,077,202,404,000$ & $448,439,756.029$ & $57,065,708,000$ \\
\hline Binjai City & 2015 & 177.248 million & $903,904,496,666$ & 489.917 million & $88,674,387,050$ \\
\hline & 2016 & $216,693,784,259$ & $985,607,494,365$ & $526,615.824,994$ & $88,674,387,050$ \\
\hline & 2017 & $180,664,010,530$ & $873,467,187,310$ & $438,353,593.115$ & $98,283,092,444$ \\
\hline & 2018 & $212,612,965,741$ & $948,180,431,992$ & $458,755.813 .009$ & $136,033,147,992$ \\
\hline Medan city & 2019 & $78,230,946,876$ & $870,461,218,147$ & 463.056 .049 .170 & $138,085.857,147$ \\
\hline & 2015 & $1,080,390,000,000$ & $4,683,063,608,825$ & $1,906,750,000,000$ & $1,679,235,018,825$ \\
\hline & 2016 & $1,190,129,261,883$ & $5,203,526.015,404$ & $2,131,490,985,977$ & $1,827,196,828,389$ \\
\hline & 2017 & $1,352,895,789,273$ & 5.264 .198 .010 .129 & $1,860,111,217,245$ & $1,973,780,338,563$ \\
\hline & 2018 & $1,168,438,057,824$ & $5,238,966,379,116$ & $1,846,286.022 .846$ & $2,112,663,059,116$ \\
\hline & 2019 & $1,234,065,029,448$ & $6,118,774,024,238$ & $1,973,029,342,159$ & $2,338,282,166,448$ \\
\hline
\end{tabular}

According to (Halim, 2008) the ratio of regional income growth can show how much ability the local government has to maintain or increase its revenue growth from one period to the next. The higher growth of regional income and a positive value every year indicates that the regional government has been able to increase the growth of its regional income. Regional income growth has increased every year causing local governments to be able to meet all regional needs and provide an indication that regional finances have been able to be managed properly by local governments.

\section{LITERATURE REVIEW}

\subsection{Capital Expenditure}

Capital expenditures are closely related to investments made by local governments.(Halim, 2008b)states that the word investment can be interpreted in various ways depending on the point of view or context in which it is interpreted. In the language of macroeconomics investment can be interpreted differently from the language of microeconomics, and can also be interpreted differently from the language of accounting. In the language of accounting in the context of the type of expenditure/cost, investment can arise from the difference between revenue expenditure and capital expenditure. Investments included in the definition of capital expenditures are capital expenditures, which are defined as expenditures/costs/expenditures that provide benefits for more than one year. In PP No. 58 of 2005 stated that capital expenditures are expenditures made in the context of purchasing/procuring fixed assets and other assets that have a useful life of more than 12 (twelve) months to be used in government activities.

\subsection{Local Government Size}

The size of the local government is one of the variables in the size of the government of a region which can be measured by total assets, number of employees, total income and productivity levels (Damanpour, 1991). The size of the local government shows how big the local government is. With a larger number of assets/employees/productivity, it is expected to have better financial performance than smaller areas (Patrick, 2007) in Lesmana (2010). In this study, total revenue was chosen as a benchmark in determining the size of a local government. Total income was chosen because its value is more stable than the number of employees or the total production of an area. Lesmana (2010), Sumarjo (2010), Yulianingtyas (2011) and Syafitri (2012) use the size of total assets in measuring the size of the government. 


\subsection{Remaining More Budget Financing}

Exceeding the SiLPA target sourced from exceeding the regional revenue target and efficiency is highly expected, while those originating from the absence of development programs/activities, especially in unreasonable amounts, are very detrimental to the community. SiLPA is also used for crucial issues that were previously approved by the legislature. SiLPA, which tends to be large, shows the weakness of the executive in planning and managing funds. Most of the SiLPA is used for direct expenditures in the form of capital expenditures that directly touch the needs of the community. The amount of direct expenditure can be in the form of infrastructure development, asset procurement, and so on. SILPA according to Government Regulation Number 58 of 2005 is the excess of the realization of budget revenues and expenditures during one budget period.

\section{IMPLEMENTATION METHOD}

The sample in this study amounted to 6 regencies/cities in the province of North Sumatra at the Directorate General of Fiscal Balance. Publish financial reports and annual reports for 2015-2019 which can be accessed through the website of the Ministry of Finance of the Republic of Indonesia (http://www.djpk.kemenkeu.go.id/portal/data/tkdd. The type of data used in this study is quantitative data, in the form of an explanation of the financial statements. The source of data in this study is secondary data. Descriptive statistics are used to analyze data by describing a sample of data that has been collected in actual conditions, without the intention of making generalized conclusions and generalizations.

\section{RESULTS AND DISCUSSION}

\subsection{T-Test Results (Partial Test)}

Test $t$ is used to determine the ability of each Independent variable individually (partial) in explaining the behavior of the dependent variable. The test was carried out using a significance level of $0.05(\alpha=5 \%)$. The rejection or acceptance of the hypothesis is carried out with the following criteria: If the significance value is less than or equal to 0.05 then the hypothesis is accepted which means that partially X1, X2 and X3 variables affect Government Financial Performance. If the significance value is more than 0.05 , the hypothesis is rejected, which means that partially $\mathrm{X} 1, \mathrm{X} 2$ and X3 variables have no effect on Government Financial Performance.

Table 1 T-Test Results (Partial Test)

Coefficientsa

\begin{tabular}{|c|c|c|c|c|c|c|c|}
\hline \multirow[b]{2}{*}{ Model } & \multicolumn{2}{|c|}{$\begin{array}{l}\text { Unstandardized } \\
\text { Coefficients }\end{array}$} & \multirow{2}{*}{\begin{tabular}{|c|}
$\begin{array}{c}\text { Standardized } \\
\text { Coefficients }\end{array}$ \\
Beta \\
\end{tabular}} & \multirow[b]{2}{*}{$\mathrm{t}$} & \multirow[b]{2}{*}{ Sig. } & \multicolumn{2}{|c|}{$\begin{array}{l}\text { Collinearity } \\
\text { Statistics }\end{array}$} \\
\hline & $\mathrm{B}$ & Std. Error & & & & Tolerance & VIF \\
\hline (Constant) & $-32,352$ & 6.514 & & $-4,966$ &, 000 & & \\
\hline Capital Expenditure & ,416 & ,212 & ,238 & 1,962 & ,061 & ,483 & 2.070 \\
\hline $\begin{array}{l}\text { Local Government } \\
\text { Size }\end{array}$ &, 539 &, 159 &, 385 & 3,384 & ,002 &, 549 & 1,823 \\
\hline $\begin{array}{l}\text { Remaining More } \\
\text { Budget Financing }\end{array}$ & 1.183 & ,332 & ,418 & 3,559 & .001 &, 516 & 1,937 \\
\hline
\end{tabular}

a. Dependent Variable: Financial Performance

The results of regression testing for the first hypothesis in this study were conducted to determine whether Capital Expenditures have an effect on Financial Performance. The test results show that the regression coefficient value of the Capital Expenditure variable (X1) is $1=0.416$ with a significance value of 0.061 . Hypothesis testing shows that if the value of Sig. > 0.05 then $\mathrm{Ha}$ is accepted, i.e. Capital Expenditure has no effect on Financial Performance in Regency/City Governments in North Sumatra Province. 


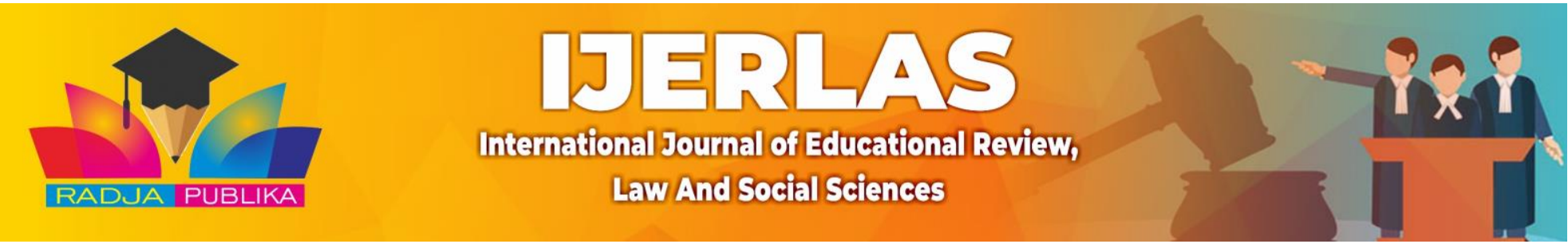

The results of regression testing for the second hypothesis in this study were conducted to determine whether the size of the local government has an effect on financial performance. The test results show that the regression coefficient value of the Regional Government Size variable (X2) is $2=0.539$ with a significance value of 0.002 . Hypothesis testing shows that if the value of Sig. $<0.05$ then $\mathrm{Ha}$ is rejected, i.e. the size of the local government affects the financial performance of the district/city government in the province of North Sumatra.

The results of regression testing for the third hypothesis in this study were conducted to determine whether the remaining excess of budget financing has an effect on financial performance. The test results show that the regression coefficient value for the variable Remaining Budget Financing (X3) is $3=1.183$ with a significance value of 0.001 . Hypothesis testing shows that if the value of Sig. $<0.05$ then Ha is rejected, i.e. the remaining budget financing has an effect on the financial performance of the district/city government in the province of North Sumatra.

\subsection{F Test Results (Test)}

Test this is done to test the independent variables on the dependent variable together. The test was carried out using a significance level of $0.05(\alpha=5 \%)$. If the significance value is less than or equal to 0.05 then the hypothesis is accepted, which means that the variables X1, X2 and X3 together have an effect on the Government Financial Performance variable. If the significance value is more than 0.05 then the hypothesis is rejected, which means that the variables $\mathrm{X} 1, \mathrm{X} 2$ and $\mathrm{X} 3$ together have no effect on the Government Financial Performance variable. The results of the F test can be seen in Table IV.6 below.

Table 2 F Test Results ANOVAa

\begin{tabular}{|ll|r|r|r|r|r|}
\hline \multicolumn{1}{|c|}{ Model } & Sum of Squares & df & Mean Square & F & Sig. \\
\hline & Regression & 38,581 & 3 & 12,860 & 38,234 &, $000 \mathrm{~b}$ \\
Residual & 8.745 & 26 &, 336 & & \\
Total & 47,326 & 29 & & & \\
\hline
\end{tabular}

a. Dependent Variable: Financial Performance

b. Predictors: (Constant), Remaining Budget Financing, Size of Local Government, Capital Expenditure

Source: Processed Secondary Data, 2020

The results of regression testing for the fourth hypothesis in this study were conducted to determine whether Capital Expenditures, Size of Local Governments, and Excess Budget Financing together have an effect on Financial Performance. The test results show the Fcount value of 38.234 with a significance value of 0.000 . Hypothesis testing shows that if the value of Sig. $<0.05$ then Ha is accepted, namely Capital Expenditure, Size of Local Government, and Remaining Over Budget Financing together affect the Financial Performance of Regency/City Local Governments in North Sumatra Province.

\section{DISCUSSION}

\subsection{Effect of Capital Expenditure on Financial Performance}

The results of regression testing for the first hypothesis in this study were conducted to determine whether capital expenditures have an effect on financial performance. The test results show that the regression coefficient value of the Capital Expenditure variable (X1) is $1=0.416$ with a significance value of 0.061 . Hypothesis testing shows that if the value of Sig. $<0.05$ then Ha is accepted, ie Capital Expenditure has no effect on Financial Performance in Regency / City Governments in North Sumatra Province.(Bojanic, 2013) and (Chude, 2013)argues that capital expenditure can increase the level of people belonging to the lower classes. The high capital expenditure causes the higher the productivity of the economy which in this case is the performance of the local government(Saputra, 2014). Although capital expenditures can accelerate economic 
growth, local governments still have to control and adjust their regional expenditures so that they do not exceed their income. An increase in funds used for government spending without a corresponding increase in revenue can lead to a budget deficit(Nwosu, Damian C., 2014).

\subsection{The Effect of Local Government Size on Financial Performance}

The results of regression testing for the second hypothesis in this study were conducted to determine whether the size of the local government has an effect on financial performance. The test results show that the regression coefficient value of the Regional Government Size variable (X2) is $2=0.539$ with a significance value of 0.002 . Hypothesis testing shows that if the value of Sig. $<0.05$ then $\mathrm{Ha}$ is rejected, i.e. the size of the local government affects the financial performance of the district/city government in the province of North Sumatra. The size of the local government is one of the variables in the size of the government of a region which can be measured by total assets, number of employees, total income and productivity level (Damanpour, 1991). In this research, total assets or total assets of local government is chosen as a benchmark in determining the size of a local government. Total assets were chosen because their value is more stable than income, number of employees or total production of an area. Local governments with large sizes are required to carry out transparency in financial management as a form of public accountability through the disclosure of more information in financial reports.

\subsection{The Effect of Excess Budget Financing on Financial Performance}

The results of regression testing for the third hypothesis in this study were conducted to determine whether the remaining excess of budget financing has an effect on financial performance. The test results show the regression coefficient value for the variable Remaining Budget Financing (X3) of $3=1.183$ with a significance value of 0.001 . Hypothesis testing shows that if the value of Sig. $<0.05$ then $\mathrm{Ha}$ is rejected, i.e. the remaining excess of budget financing has no effect on the financial performance of the district/city government in the province of North Sumatra. Excess Budget Financing (SILPA) based on Permendagri No. 13 of 2006 is the difference in the realization of budget revenues and expenditures during one budget period. SILPA of the previous fiscal year includes exceeding PAD receipts, exceeding balance fund receipts, exceeding other legitimate regional revenues, exceeding financing receipts, saving expenditures, obligations to third parties until the end of the year have not been resolved, and remaining funds for follow-up activities. SILPA is an indicator that describes the efficiency of government spending. SILPA is actually an efficiency indicator, because SILPA will only be formed if there is a surplus in the APBD and at the same time there is positive net financing, where the revenue component is greater than the financing expenditure component.(NTT, 2008).

\subsection{Effect of Capital Expenditure, Size of Local Government, and Remaining Budget Financing on Financial Performance}

The results of regression testing for the fourth hypothesis in this study were conducted to determine whether Capital Expenditures, Size of Local Government, and Excess Budget Financing together have an effect on Financial Performance. The test results show the Fcount value of 38.234 with a significance value of 0.000 . Hypothesis testing shows that if the value of Sig. $<0.05$ then Ha is accepted, namely Capital Expenditure, Size of Local Government, and Remaining Over Budget Financing together have an effect on Financial Performance in Regency / City Governments in North Sumatra Province. The results of the coefficient of determination test obtained an R-Square value of 0.815 or $81.5 \%$. This shows that the variables of Capital Expenditure, Size of Local Government, and Remaining Budget Financing is able to explain the Financial Performance variable of $81.5 \%$. While the remaining $18.5 \%$ is explained by other variables outside the study. This research has also been conducted by (Sri Mulyani Hardiyanto Wibowo, 2017) where the results of the analysis show that the capital expenditure variable has a significant positive effect on the financial performance of the district/city government of Central Java Province. Meanwhile, the variables of intergovernmental 


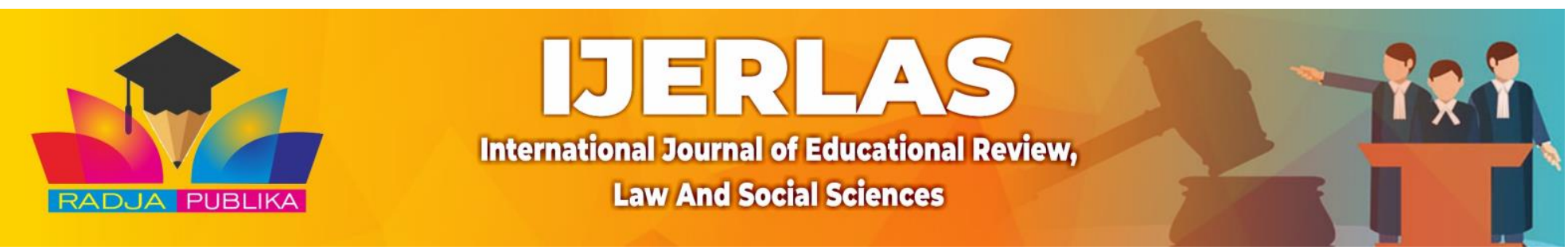

revenue, the size of the local government and the local revenue have a significant negative effect on the financial performance of the district/city government of Central Java Province in 2012-2015. 2017) where the results of the analysis show that the capital expenditure variable has a significant positive effect on the financial performance of the district/city government of Central Java Province. Meanwhile, the variables of intergovernmental revenue, the size of the local government and the local revenue have a significant negative effect on the financial performance of the district/city government of Central Java Province in 2012-2015. 2017) where the results of the analysis show that the capital expenditure variable has a significant positive effect on the financial performance of the district/city government of Central Java Province. While the variables of intergovernmental revenue, the size of the local government and local revenue have a significant negative effect on the financial performance of the district/city government of Central Java Province in 2012-2015.

\section{CONCLUSION}

This study aims to determine the effect of capital expenditure, the size of the local government and the remaining excess budget financing (SILPA) on financial performance by using multiple linear regression analysis. Based on the results of the study obtained the following conclusions. Capital Expenditures have no partial effect on the Financial Performance of district/city governments in North Sumatra Province. This result is obtained from the regression coefficient value of the Capital Expenditure variable $(\mathrm{X} 1)$ of $1=0.416$ with a significance value of 0.061 . Hypothesis testing shows that if the value of Sig. $>0.05$ then Ha is accepted, i.e. Capital Expenditure has no effect on Financial Performance in Regency/City Governments in North Sumatra Province. The size of the local government partially affects the financial performance of district/city governments in North Sumatra Province. This result is obtained from the regression coefficient value of the Regional Government Size variable (X2) of $2=0.539$ with a significance value of 0.002 . Hypothesis testing shows that if the value of Sig. $<0.05$ then Ha is rejected, i.e. the size of the local government affects the financial performance of the district/city government in the province of North Sumatra. The Excess of Budget Financing partially affects the Financial Performance of district/city governments in North Sumatra Province. This result is obtained from the regression coefficient value of the variable remaining budget financing (X3) of $3=1.183$ with a significance value of 0.001 . Hypothesis testing shows that if the value of Sig. < 0, 05 then $\mathrm{Ha}$ is rejected, i.e. Remaining Budget Financing has an effect on Financial Performance in Regency/City Governments in North Sumatra Province. Remaining Capital Expenditures, Size of Local Governments, and Over Budget Financing together have an effect on Financial Performance in district/city governments in North Sumatra Province. This result is obtained from the Fcount value of 38.234 with a significance value of 0.000 . Hypothesis testing shows that if the value of Sig. < 0.05 then Ha is accepted, namely Capital Expenditure, Size of Local Government, and Remaining Over Budget Financing together affect the Financial Performance of Regency/City Local Governments in North Sumatra Province. The R-Square value is 0.815 or $81.5 \%$. This shows that the variables of Capital Expenditure, Size of Local Government, and Remaining Budget Financing is able to explain the Financial Performance variable of $81.5 \%$. While the remaining $18.5 \%$ is explained by other variables outside the study. 


\section{REFERENCES}

Abidin, M. B. (2017). Pengaruh Karakteristik Pemerintah Daerah Terhadap Kinerja Keuangan. (Fakultas E).

Alexiou, C. (2009). Government Spending and Economic Growth : Econometric Evidence from the South Eastern Europe. Journal of Economic and Social Research, 11(1), 1-16.

Alpi, M. F. (2019). Penerapan Good Corporate Governance pada PT. Bank BUMN Tbk Regional I Sumatera Utara. Proseding Seminar Nasional Kewirausahaan, 1(1), 355-364.

Alpi, M. F., \& Ramadhan, P. R. (2018). Pengaruh karakteristik pemerintah daerah dan temuan audit Badan Pemeriksa Keuangan terhadap kinerja keuangan kabupaten/kota. Jurnal Studi Akuntansi \& Keuangan, 2(3), 103-114.

Alvini, Y. (2018). Pengaruh Ukuran Pemerintah Daerah, Tingkat Kekayaan Daerah, Tingkat Ketergantungan Daerah Kepada Pemerintah Pusat dan Belanja Modal Terhadap Kinerja Keuangan Pemerintah Daerah (Studi pada Kabupaten/Kota se-Provinsi Riau Periode 20112016). JOM FEB, 1(1), 1-15.

Andirfa, Mulia., Hasan Basri., M. S. A. M. (2016). Pengaruh Belanja Modal, Dana Perimbangan, dan Pendapatan Asli Daerah terhadap Kinerja Keuangan Kabupaten dan Kota di Provinsi Aceh. Jurnal Magister Akuntansi, 5(3), 30-38.

Andirfa, M. (2016). Pengaruh Belanja Modal, Dana Perimbangan dan Pendapatan Asli Daerah Terhadap Kinerja Keuangan Kabupaten dan Kota Di Provinsi Aceh. aceh: Universitas Syiah Kuala Banda Aceh.

Aziz, A. (2016). Pengaruh Karakteristik Pemerintah Daerah Terhadap Kinerja Keuangan Pemerintah Daerah (Studi Pada Pemerintah Daerah Kabupaten / Kota Di Jawa Timur). Universitas Islam Majapahit, 11(1).

Bojanic, A. N. (2013). The Composition of Government Expenditure and Economic Growth in Bolivia. Journal of Economic, 50(1), 83-105.

Brusca, Isabel., Francesca Manes Rossi., N. A. (2015). Drivers for The Financial Condition of Local Government: A Comparative Study Between Italy and Spain. Journal of Local SelfGovernment, 13(2), 161-184.

Chude, N. P. and D. I. C. (2013). Impact of Government Expenditure on Economic Growth in Nigeria. International Journal of Business and Management Review, 1(4), 64-71.

Darwanto, Y. dan. (2007). Pengaruh Pertumbuhan Ekonomi, Pendapatan Asli Daerah, Dan Dana Alokasi Umum Terhadap Pengalokasian Anggaran Belanja Modal.

Felix, O. (2012). Analysis of the effectiveness of capital expenditure budgeting in the local government system of Ondo State. Journal of Accounting and Taxation, 4(1), 1-6.

Halim, A. (2008a). Akuntansi Keuangan Daerah. Jakarta: Salemba Empat.

Halim, A. (2008b). analisis investasi (belanja modal) Sektor-publik Pemerintah daerah. Yogyakarta.

Kusumawardani, M. (2012). Pengaruh Size, Kemakmuran, Ukuran Legislatif, Leverage Terhadap Kinerja Keuangan Pemerintah Daerah Di Indonesia (Fakultas E). Skripsi semarang.

Liliana, Bunescu, M. D. and C. C. (2011). Is There a Correlation between Government Expenditures, Population, Money Supply, and Government Revenues? International Journal of Arts \& Sciences, 241-254.

Mardiasmo. (2009). Otonomi Daerah Sebagai Upaya Memperkokoh Basis Perekonomian Daerah. Makalah. Seminar Pendalaman Ekonomi Rakyat.

Modebe, N.J., Regina G. Okafor, J. U. . O. and I. G. I. (2012). Impact of Recurrent and Capital Expenditure on Nigeria's Economic Growth. European Journal of Business and Management, 4(9), 66-74.

Mulyani, S. dan H. W. (2017). Pengaruh Belanja Modal, Ukuran Pemerintah Daerah, Intergovernmental Revenue dan Pendapatan Asli Daerah terhadap Kinerja Keuangan. Kompartemen, 15(1), 57-66.

Nosihana, A \& Yaya, R. (2016). Internet Financial Reporting dan Faktor-Faktor yang 


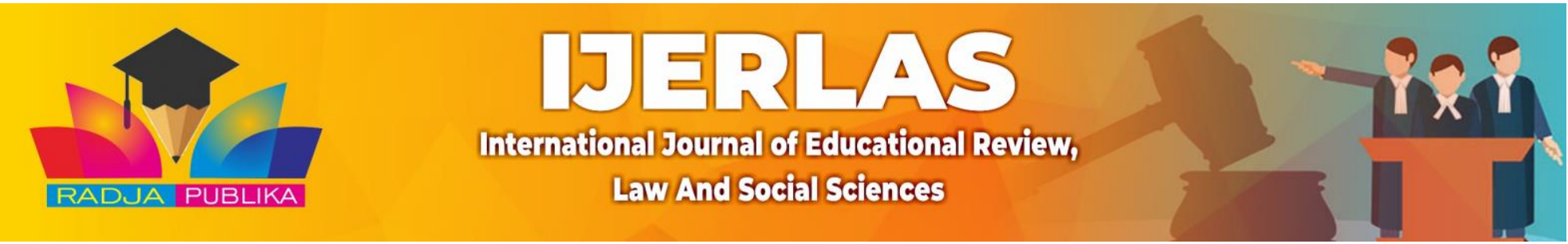

Mempengaruhinya Pada Pemerintah Kota dan Kabupaten Di Indonesia. Jurnal Dinamika Akuntansi Dan Bisnis, 3(2), 87-101.

NTT, B. P. (2008). Analisis Tentang Tingkat Efiseinsi Dan Efektivitas Pengeluaran Pemerintah Terhadap Pembangunan Daerah di Provinsi Nusa Tenggara Timur. Jurnal Litbang NTT, 4(3).

Nwosu, Damian C., and H. O. O. (2014). Government Revenue and Expenditure In Nigeria: A Disaggregated Analysis. Asian Economic and Financial Review, 4(7), 877-892.

Patrick, P. A. (2007). The Determinant of Organizational Inovativeness:The Adoption of GASB 34 in Pennsylvania Local Government. (Unpublishe). State University.: The Pennsylvania State University.

Puspitasari, N.L.P. Lindri., M. Pradana Adiputra., N. L. G. E. S. (2015). Pengaruh Belanja Modal terhadap Pertumbuhan Kinerja Keuangan Daerah dengan Pendapatan Asli Daerah Sebagai Variabel Intervening. E-Journal S1 AK Universitas Pendidikan Ganesha, 3(1).

Restianto, S. dan. (2011). Pengaruh Kinerja Keuangan Terhadap Alokasi Belanja Modal dan Pertumbuhan Ekonomi Kabupaten/Kota Di jawa Tengah. Universitas Jendral Soedirman, Purwokerto.

Saputra, D. dan R. (2014). Pengaruh Belanja Modal terhadap Pendapatan Asli Daerah dan Dampaknya pada Kinerja Keuangan Pemerintah Daerah. Jurnal Dinamika Akuntansi Dan Bisnis, 1(2), 183-199.

Sari, M. (2018). Penerapan Good Corporate Governance Dalam Meningkatkan Kinerja Keuangan. Prosiding The National Conferences Management and Business (NCMAB), 17-27.

Sharma, B. (2012). Government expenditure and economic growth in Nepal: a minute analysis. Journal of Business Management and Accounts, 1(4), 37-40.

Sinambela, E., Saragih, F., \& Sari, E. N. (2018). Analisis Struktur APBD Dalam Meningkatkan Pengelolaan Keuangan Daerah Pada Pemerintah Daerah Sumatera Utara. Jurnal Ilmu Ekonomi Dan Studi Pembangunan, 18(2), 93-101.

Sinta, I. ., Tambarta Kembaren, E. ., \& F, F. (2021). CONJUCTURE EFFECT OF OPERATIONAL COST FOR INCREASING FINANCIAL PERFORMANCE PT. GOTONG ROYONG JAYA. International Journal of Economic, Business, Accounting, Agriculture Management and Sharia Administration (IJEBAS), 1(1), 54-61. https://doi.org/10.54443/ijebas.v1i1.5

Suryabrata, S. (2000). Pengaruh Kinerja Keuangan Terhadap Alokasi Belanja Modal dan Pertumbuhan Ekonomi Kabupaten/Kota Di jawa Tengah. Universitas Jendral Soedirman, Purwokerto. 
Determinant Model Of District/City Government Financial Performance In Sumatera Utara Province DOI: $10.54443 /$ ijerlas.v1i2.73 